the restricted field of medical research dealt with, British contributions stand in the eyes of a distinguished foreigner. To the British research worker it must afford an unusual experience of seeing some of the fruits of modern medical research in his country receiving adequate appraisal when placed in an international setting. The fact that the book was written primarily for foreign eyes gives it a special value as evidence of the high standing of our medical research. We owe a great debt of gratitude to Dr. Jaramillo-Arango for having undertaken this imaginative tribute to Great Britain, and in return must express our real appreciation of his scholarly and interesting book.

\section{SCIENCE IN CRIMINOLOGY}

Medical and Scientific Investigations in the Christie Case

By Dr. Francis E. Camps. Pp. xxiii $+244+6$ plates. (London: Medical Publications, Ltd., 1953.) 30s. net.

D ELATIVELY few criminal cases afford the opportunity for any extensive exercise in the forensic sciences. R. $v$. Ruxton and R. $v$. Haigh offered much in reconstruction data for identity, and R. $v$. Dobkin had the added interest of dental detail of exceptional quality and of evidence as to the cause of death. The recent case of R. $v$. Christie has renewed interest in these problems-in methods of ageing, sexing and height estimation in human remains, in the detection of a cause of death after a long interval of time, and the ever-difficult problem of determining the lapse of time since death. It also provided another problem-how to present such evidence at court in the most easily assimilable form: science must be made both reasonable and palatable to lay juries.

This record by Dr. F. E. Camps of the evidence in R. $v$. Christie is not so much his work as that of a team of experts whose specialities-microscopy, analytical chemistry, mycology, dental histology, anatomy, radiology and Dr. Camps's own forensic pathology-combined to forge the links in the evidence presented by the Crown for the prosecution in corroboration of the statements of admission of guilt made by the accused. Like all edited books, it lacks a uniformity of style and reveals both talent and mediocrity in prose-writing. It is in the content of scientific data that its chief attraction lies.

The most polished pieces of work are undoubtedly those of Prof. A. E. W. Miles on the study of the teeth and of Dr. Richard Harrison on the anatomical problems of sexing, ageing and giving stature to the skeletal remains: each is excellently illustrated and well tabulated. Gustafson's modern 'points method' for ageing teeth and of using incremental patterns to assign them to individuals receives some further support, and the superiority of the formulæ of Trotter and Gleser for stature-estimates over the older Rollet, Pearson or even Dupertuis and Hadden formulæ is amply reflected: older tables all showed a tendency to under-estimation. Incidentally, it is to be noted that neither Dr. Camps nor his dental advisers seem to have read the descriptions of 'pink teeth' in the dead by both Thomas Bell in 1829 or of his pupil, the famous Tomes, for they study at some length the nature of the 'new observation', now more than a century old; little, indeed, is new when one comes to search the literature.
A chapter on the known facts of coal-gas absorption factors by the Gas Board expert, F. C. Smith, tends to elaborate somewhat tediously the standard writings on the subject; but one must remember that this book is plainly intended for interested lay consumption as well as medical and scientific. Major H.A. Dade records the surprisingly restricted mycological findings of the intact bodies-almost entirely of common and ubiquitous moulds-Mucor racemosus Fresen, Penicillium cyclopium; it would have been of interest to have recorded the temperature-ranges for growth of these moulds.

The book is completed by the addition of Christie's three statements, which afforded a great deal of 'testing evidence', and of a short account of the Scott Henderson inquiry which followed public outery over the prior execution of Evans who had lived with Christie at a material time.

Anyone interested in the application of scientific knowledge to the needs of the law in criminal investigation will find much of interest here: it is a good example of the demands for team-work which occasionally arise in the course of a practice in forensic medicine and criminology, and Medical Publications, Ltd., have made an excellent job of reproduction and illustration on first-class paper. It is not to be recommended to the amateur sleuth, the writer of detective thrillers or the morbidly curious, for it is a serious scientific account of laboratory and fieldinvestigations.

KEITH SIMPSON

\section{POISONOUS PLANTS OF INDIA}

\section{Poisonous Plants of India}

Vol. 1. By Sir Ram Nath Chopra, Rattan Lall Badhwar and Prof. Sudhamoy Ghosh. (The Indian Council of Agricultural Research: Scientific Monograph No. 17.) Pp. liv +762. (Delhi: Manager of Publications, 1949.) 30 rupees.

ATHOUGH the title-page is dated 1949, this A book has only recently appeared after a "labour" which has lasted about fourteen years. The manuscript was sent to the press at the beginning of the Second World War ; but owing to vexatious delays due to shortage of paper, and for other reasons, the first volume did not leave the printers' hands until 1949. Shortly after it appeared, the volume was recalled for some correction and has only lately been issued to the public. The welcome which it is sure to receive will be some recompense to the authors for their frustration.

In their preface the authors state that it is their aim to survey the whole field of poisonous plants in India from the botanical, chemical, pharmacological and economic angles. This aim has been achieved; but it is open to question whether it would not have been better to exclude a great deal of the botanical matter. Botanists who use the book will not be interested in the botany as such, for which they have other sources, and non-botanists will only be interested in the plants and their products.

This is only a trifling criticism; but the size of the book might have been considerably reduced without sacrificing any of the really important matter in it-which is undoubtedly the account of the poisonous products contained in the tissues of the plants themselves. The information given on this subject is thorough and reasonably up to date, although much work on poisonous drugs found in 